\title{
Blood pressure in first 10 years of life: the Brompton study
}

\author{
Michael de Swiet, Peter Fayers, Elliott A Shinebourne
}

\section{Abstract}

Objectives-To determine the normal range of blood pressure and its pattern of change in the first 10 years of life. To estimate at what age (if any) children consistently appear in one part of the blood pressure distribution and at what age familial correlations in blood pressure become significant.

Design-Longitudinal cohort study.

Setting-South east England.

Subjects - 2088 children of both sexes born consecutively in Farnborough Hospital, Kent, and their parents.

Main outcome measure-Blood pressure measured by Doppler ultrasonography and sphygmomanometry.

Results-Systolic blood pressure rose from a mean of $88.5 \mathrm{~mm} \mathrm{Hg}$ at age 6 months to $96.2 \mathrm{~mm} \mathrm{Hg}$ at 8 years measured with a $8 \mathrm{~cm}$ cuff and from $89.1 \mathrm{~mm} \mathrm{Hg}$ at age 5 years to $94.3 \mathrm{~mm} \mathrm{Hg}$ at age 10 years measured with a $12 \mathrm{~cm}$ cuff. The larger cuff gave blood pressure readings about $6 \mathrm{~mm} \mathrm{Hg}$ lower. This effect was independent of body weight and arm circumference. Diastolic blood pressure rose from $57.8 \mathrm{~mm} \mathrm{Hg}$ at 5 years to $61.8 \mathrm{~mm} \mathrm{Hg}$ at 10 years $(12 \mathrm{~cm}$ cuff). There was only about $1 \mathrm{~mm} \mathrm{Hg}$ difference between sexes. Blood pressure was correlated with weight, weight adjusted for height, height, and arm circumference at all ages studied. The correlation coefficient of repeated yearly measurements increased steadily with age from 0.28 at 2 years to 0.59 at 10 years. The correlation coefficients between child's blood pressure and mother's average blood pressure increased from 0.1 at age 1 year to 0.23 at age 10 .

Conclusions-Blood pressure changes relatively little between the ages of 6 months and 10 years. Yet because of the increasing strength of between occasion and family correlations, children are more consistently occupying a specific part of the blood pressure distribution as they grow older. Studies in children should help determine why some adults have hypertension and others do not.

\section{Introduction}

Most studies of blood pressure in children have either examined small groups of children ${ }^{1}$ or have been cross sectional. ${ }^{2}$ The Brompton study is the first to follow one large group of children from birth until 10 years. This is important because changes in blood pressure at certain ages, such as those noted by the Task Force for Blood Pressure Control ${ }^{3}$ at age 6 years, may represent differences in methods between studies of different groups of children rather than a genuine difference in blood pressure at this age. The Brompton study has also allowed examination of tracking phenomenon: At what age, if any, do children consistently appear in one part of the blood pressure distribution and what factors influence which part of the blood pressure distribution they occupy? We have presented reports concerning the blood pressure distribution up to age 6 years and tracking in the first 5 years of life. ${ }^{45}$

\section{Subjects and methods}

The parents of 2088 children born consecutively at Farnborough Hospital, Kent, between April 1975 and
May 1977 were approached for permission to enter their children into the study. The only exceptions were parents who knew that they would be moving from the neighbourhood within six months. The parents of 88 children refused to participate, and 105 children were born before 37 weeks' gestation, leaving a total of 1895 in the study.

Nurses measured the blood pressures of the children using the non-invasive Parks Doppler ultrasound system $^{6}$ and random zero sphygmomanometry at the approximate ages of 4 days, 6 weeks, 6 months, 1 year, and yearly thereafter until May 1986. Thus all the children remaining in this study were at least 9 years old and some were 10 . At each age three readings were taken immediately after each other and the mean of these three values was taken as the blood piessure. From the age of 4 years, blood pressure was measured by the Doppler system followed by conventional sphygmomanometry, taking the fifth Korotkoff sound as the diastolic pressure. Three sphygmomanometer cuff sizes were used: $4 \mathrm{~cm}, 8 \mathrm{~cm}$, and $12 \mathrm{~cm}$ cuffs with inflation bags measuring $4 \times 13 \mathrm{~cm}, 8 \times 12 \mathrm{~cm}$, and $12 \times 36 \mathrm{~cm}$ respectively. The largest cuff that could be comfortably applied to the child's upper arm was always used. In young children we have found no significant differences between intra-arterial and Doppler blood pressure measurements using these cuffs. ${ }^{6}$ However, as the children grew older, systematic differences emerged in blood pressures, depending on the cuff used, that were independent of the relation between blood pressure and weight or arm circumference. The differences in blood pressure were small, being about $5 \mathrm{~mm} \mathrm{Hg}$ between the $8 \mathrm{~cm}$ and $12 \mathrm{~cm}$ cuffs. Nevertheless, we have presented the blood pressures according to the cuff used.

Blood pressure was always measured on the right arm. Infants were studied lying flat, but after the age of 1 year blood pressure was measured sitting, with children at first in their mothers' laps and later on a chair. From the age of 4 years the children were rested for five minutes before taking measurements. No measurements were made while the children were eating or sucking (especially important in the infants) or ill. Children were arbitrarily classified as ill if they were taking prescribed medicine. Children were weighed on bathroom scales, and their heights were measured (after 4 years) with a tape measure whenever blood pressure was measured.

Most $(69 \%)$ of the measurements in children aged 4 days were made at home; the remainder were made in hospital. Measurements in children aged 6 weeks to 3 years were all made at home. At 4 years, we started making measurements at the children's schools, and by the age of 8 most (95\%) were made at school. Infants were classified as awake if their eyes were open at the beginning of blood pressure measurement. ${ }^{7}$ After the age of 1 year all the children were awake when they were studied. Only 449 children were studied at age 10 years compared with over 900 at all other ages. This was because the funding for the project related to calendar time rather than children's age.

We also measured the mother's blood pressure by conventional sphygmomanometry whenever the child's blood pressure was measured in hospital or at home. Father's blood pressure was measured at least once for $68 \%$ of the children. Further details of the methods are given elsewhere. ${ }^{5-7}$
London W6 0XG.

$B M 7$ 1992;304:23-6 


\section{STATISTICS}

We analysed the data using the statistical package for the social sciences (SPSS). Serial pairwise correlation coefficients of blood pressure throughout the study period were calculated. However, because blood pressure is correlated with weight $t^{5}$ and weight showed significant serial correlations (fat children tended to remain fat) we also calculated serial correlation of blood pressure adjusted for a function of weight. In a previous paper we used Quetelet's index (weight/ height $^{2}$ ) to study the relation of blood pressure to obesity rather than to weight alone. However, this index varies with age and is not appropriate for schoolchildren. ${ }^{8}$ Therefore in this study we used the index of Cole ${ }^{8}$ which takes into account the effect of age: (weight/excess weight for age) $\times$ (excess height for age/height $)^{p}$, where $p$ is a function of age with values between 2 and $3 .^{8}$

\section{Results}

Table I shows the number of children lost to follow up and those remaining in the study. Most children were lost because they moved out of the area rather than because they, or their parents, did not wish to participate. After a rapid initial loss of 300 children in the first year, there was a steady loss of $2-6 \%$ a year; in

TABLE I - Numbers of children studied and lost to follow up

\begin{tabular}{lcccccc}
\hline Age & $\begin{array}{c}\text { No of } \\
\text { children }\end{array}$ & $\begin{array}{c}\text { No lost from } \\
\text { follow up }\end{array}$ & Deaths & No remaining & $\begin{array}{c}\text { No failed to } \\
\text { contact or ill }\end{array}$ & $\begin{array}{c}\text { No of } \\
\text { measurements } \\
\text { analysed }\end{array}$ \\
\hline 4 Days & 1895 & 88 & 10 & 1797 & 55 & 1742 \\
6 Weeks & 1797 & 20 & & 1777 & 145 & 1632 \\
6 Months & 1777 & 34 & 5 & 1738 & 178 & $867^{\star}$ \\
1 Year & 1738 & 57 & & 1681 & 253 & $1323^{\star}$ \\
2 Years & 1681 & 109 & 2 & 1570 & 248 & 1322 \\
3 Years & 1570 & 85 & 1 & 1484 & 266 & 1218 \\
4 Years & 1484 & 80 & 1 & 1403 & 254 & 1149 \\
5 Years & 1403 & 64 & & 1339 & 344 & 995 \\
6 Years & 1339 & 35 & & 1304 & 229 & 1075 \\
7 Years & 1304 & 41 & 1 & 1262 & 194 & 1068 \\
8 Years & 1262 & 27 & & 1235 & 138 & 1097 \\
9 Years & 1235 & 24 & & 1211 & 248 & 963 \\
10 Years & 1211 & & & & & $449 \dagger$ \\
\hline
\end{tabular}

*At ages 6 months and 1 year, 693 and 105 measurements were excluded because they were made with a $5 \mathrm{~cm}$ cuff which gave artificially high values.

†Incomplete follow up.

TABLE II - Systolic blood pressure ( $\mathrm{mm} \mathrm{Hg}$ ) in awake children by age and cuff size

\begin{tabular}{|c|c|c|c|c|c|c|c|c|c|}
\hline \multirow[b]{2}{*}{ Age } & \multicolumn{3}{|c|}{$4 \mathrm{~cm}$ Cuff } & \multicolumn{3}{|c|}{$8 \mathrm{~cm} \mathrm{Cuff}$} & \multicolumn{3}{|c|}{$12 \mathrm{~cm} \mathrm{Cuff}$} \\
\hline & $\begin{array}{c}\text { No of } \\
\text { children }\end{array}$ & $\begin{array}{c}\text { Mean (SD) } \\
\text { blood pressure }\end{array}$ & $\begin{array}{l}\text { 95th } \\
\text { Centile }\end{array}$ & $\begin{array}{c}\text { No of } \\
\text { children }\end{array}$ & $\begin{array}{c}\text { Mean }(\mathrm{SD}) \\
\text { blood } \\
\text { pressure }\end{array}$ & $\begin{array}{l}\text { 95th } \\
\text { Centile }\end{array}$ & $\begin{array}{l}\text { No of } \\
\text { children }\end{array}$ & $\begin{array}{c}\text { Mean (SD) } \\
\text { blood } \\
\text { pressure }\end{array}$ & $\begin{array}{l}\text { 95th } \\
\text { Centile }\end{array}$ \\
\hline 4 Days ${ }^{\star}$ & 171 & $76 \cdot 2(9 \cdot 9)$ & 95 & & & & & & \\
\hline 6 Weeks & 1129 & $95 \cdot 7(10 \cdot 7)$ & 113 & & & & & & \\
\hline 6 Months & 129 & $104 \cdot 8(10 \cdot 7)$ & 124 & 738 & $88 \cdot 5(12 \cdot 3)$ & 109 & & & \\
\hline 1 Year & & & & 1323 & $93 \cdot 4(11 \cdot 1)$ & 112 & & & \\
\hline 2 Years & & & & 1322 & $95.5(10.6)$ & 115 & & & \\
\hline 3 Years & & & & 1218 & $96 \cdot 8(9 \cdot 7)$ & 115 & & & \\
\hline 4 Years & & & & 1149 & $97 \cdot 4(9 \cdot 3)$ & 113 & & & \\
\hline 5 Years & & & & 777 & $96 \cdot 2(9 \cdot 4)$ & 114 & 218 & $89 \cdot 1(9 \cdot 3)$ & 107 \\
\hline 6 Years & & & & 449 & $95 \cdot 8(9 \cdot 1)$ & 112 & 626 & $90.0(8.2)$ & 104 \\
\hline 7 Years & & & & 187 & $97 \cdot 3(9 \cdot 2)$ & 114 & 881 & $90.0(8.6)$ & 104 \\
\hline 8 Years & & & & 55 & $96 \cdot 2(8 \cdot 6)$ & 110 & 1042 & $91.9(8.4)$ & 105 \\
\hline 9 Years & & & & & & & 963 & $92 \cdot 3(8 \cdot 7)$ & 106 \\
\hline 10 Years & & & & & & & 449 & $94.3(8.8)$ & 111 \\
\hline
\end{tabular}

*Some of the babies were asleep at time of measurement.

TABLE III-Diastolic blood pressure $(\mathrm{mm} \mathrm{Hg})$ in awake children by age and cuff size $e^{\star}$

\begin{tabular}{lccccccc}
\hline & \multicolumn{3}{c}{8 mm Cuff } & & \multicolumn{3}{c}{12 mm Cuff } \\
\cline { 2 - 3 } $\begin{array}{l}\text { Age } \\
\text { years) }\end{array}$ & $\begin{array}{c}\text { No of } \\
\text { children }\end{array}$ & $\begin{array}{c}\text { Mean (SD) } \\
\text { blood pressure }\end{array}$ & 95th Centile & & $\begin{array}{c}\text { No of } \\
\text { children }\end{array}$ & $\begin{array}{c}\text { Mean (SD) } \\
\text { blood pressure }\end{array}$ & 95th Centile \\
\hline 5 & 777 & $62 \cdot 3(9 \cdot 5)$ & 78 & & 218 & $57 \cdot 8(9 \cdot 5)$ & 73 \\
6 & 442 & $63 \cdot 6(9 \cdot 4)$ & 70 & & 621 & $59 \cdot 6(9 \cdot 5)$ & 74 \\
7 & 179 & $66 \cdot 2(7 \cdot 6)$ & 81 & & 839 & $60 \cdot 6(8 \cdot 2)$ & 75 \\
8 & 55 & $65 \cdot 2(7 \cdot 8)$ & 78 & & 1016 & $60 \cdot 7(7 \cdot 6)$ & 74 \\
9 & & & & & 954 & $60 \cdot 2(7 \cdot 6)$ & 73 \\
10 & & & & & 442 & $61 \cdot 8(7 \cdot 2)$ & 75
\end{tabular}

The numbers of children studied are less than in tables I and II because the diastolic blood pressure (Korotkoff $\mathrm{V}$ ) could not be determined for every child.
TABLE IV-Correlation coefficients of systolic blood pressure with weight, adjusted weight, height, and arm circumference; all significant at $p<0.0001$

\begin{tabular}{|c|c|c|c|c|}
\hline Age & Weight & $\begin{array}{c}\text { Adjusted } \\
\text { weight }^{\star}\end{array}$ & Height & $\begin{array}{c}\text { Arm } \\
\text { circumference }\end{array}$ \\
\hline 4 Days & $0 \cdot 30$ & & & 0.21 \\
\hline 6 Weeks & $0 \cdot 16$ & & & $0 \cdot 18$ \\
\hline 6 Months & 0.08 & & & 0.09 \\
\hline 1 Year & $0 \cdot 13$ & & & $0 \cdot 26$ \\
\hline 2 Years & $0 \cdot 14$ & & & 0.32 \\
\hline 3 Years & $0 \cdot 19$ & & & 0.31 \\
\hline 4 Years & $0 \cdot 27$ & & & 0.34 \\
\hline 5 Years & $0 \cdot 28$ & $0 \cdot 28$ & $0 \cdot 19$ & $0 \cdot 26$ \\
\hline 6 Years & $0 \cdot 26$ & 0.24 & $0 \cdot 17$ & 0.25 \\
\hline 7 Years & $0 \cdot 27$ & 0.27 & 0.22 & 0.19 \\
\hline 8 Years & $0 \cdot 34$ & 0.32 & 0.26 & $0 \cdot 28$ \\
\hline 9 Years & $0 \cdot 38$ & 0.35 & 0.29 & 0.35 \\
\hline 10 Years & $0 \cdot 41$ & 0.36 & 0.26 & $0 \cdot 40$ \\
\hline
\end{tabular}

^Weight adjusted for height and age (see text).

addition we failed to contact about 200 children (20\%) each year. There is no reason to believe that the children lost to the study had different blood pressures from those remaining. For example, the blood pressure at 4 days old in the asleep infants who remained in the study until aged 10 years was $75 \mathrm{~mm} \mathrm{Hg}$ and in those who were lost from the study by 10 years was $76 \mathrm{~mm} \mathrm{Hg}$.

Blood pressure in the boys was about $1 \mathrm{~mm} \mathrm{Hg}$ greater than in the girls at all ages $(p<0.0001)$ even after allowing for the effect of weight. However, this difference was so small that the results have been combined for further analyses. Table II gives the systolic blood pressure by age and cuff size in children awake at measurement up to age 10 . The mean difference between these measurements by Doppler ultrasonography and sphygmomanometry was small, with conventional sphygmomanometry giving slightly higher pressures (3.3 (SD 5.9) $\mathrm{mm} \mathrm{Hg}, \mathrm{n}=3939$ ), and therefore the values given for systolic blood pressure from age 4 onwards are measured by conventional sphygmomanometry as this is more representative of normal clinical practice. Mean blood pressure was lower when the larger cuff was used $(p<0.001)$ for each age group (table II). Systolic blood pressure was relatively stable between the ages of 6 months and 10 years, increasing by $8-10 \mathrm{~mm} \mathrm{Hg}$ when measured with an $8 \mathrm{~cm}$ cuff.

Table III shows similar data for diastolic blood pressure from age 5 years. Again diastolic blood pressure was lower when measured with the larger cuff, by $4.6 \mathrm{~mm} \mathrm{Hg}$ between the ages of 5 and 8 . Diastolic blood pressure rose by $4 \mathrm{~mm} \mathrm{Hg}$ between the ages of 5 and 10 years when measured with the $12 \mathrm{~cm}$ cuff.

Table IV shows that blood pressure was significantly correlated with weight, adjusted weight, and arm circumference between the ages of 4 days and 10 years. From age 5 years, when we first started measuring height, blood pressure was also significantly correlated with height but not so strongly as with weight.

To examine the tracking phenomenon we derived matrices of correlation coefficients between blood pressures for all ages at which the children were studied (table V). These correlation coefficients (tracking coefficients) were all adjusted for differences in cuff size and for small between observer and between place of measurement (home versus school) effects. The correlation coefficients generally, and gradually, became stronger as the children grew older (figure). Up to the age of 1 year, the correlation coefficients were very weak; all were less than 0.2 and at ages 4 days, 6 weeks, and 6 months blood pressures were in effect not correlated with blood pressures later in life. However, after the age of 1 year the correlations became stronger so that the one year tracking coefficients $(\mathrm{n} v \mathrm{n}-1)$ from 9 to 10 years was 0.58 . At nearly all ages the two year (n $v \mathrm{n}-2)$, three year (n $v \mathrm{n}-3)$, and 
more extended tracking coefficients were lower than the one year coefficient, but these also increased with age (figure). Adjustment of these correlations for a function of excess weight and excess height for age reduced the correlations a little but the trend was the same (table V).

We also investigated familial trends in blood pressure. At all ages up to 5 years, when the children went to school, the mothers' blood pressures were measured whenever the children were seen; the fathers' blood pressures were measured once for $68 \%$ of the children. The child's blood pressure was only weakly correlated with either simultaneously measured mother's blood pressure (aged 6 months and 4 years only) or the father's blood pressure (table VI). However, when all the mother's blood pressure measurements from the child's age of 4 days to 4 years were averaged this was correlated with the child's blood pressure with increasing strength from about 4 years onwards (table VI (figure)). Addition of the father's blood pressure measurement to give an average parents' blood pressure did not appreciably improve the correlation with the child's blood pressure (table VI).

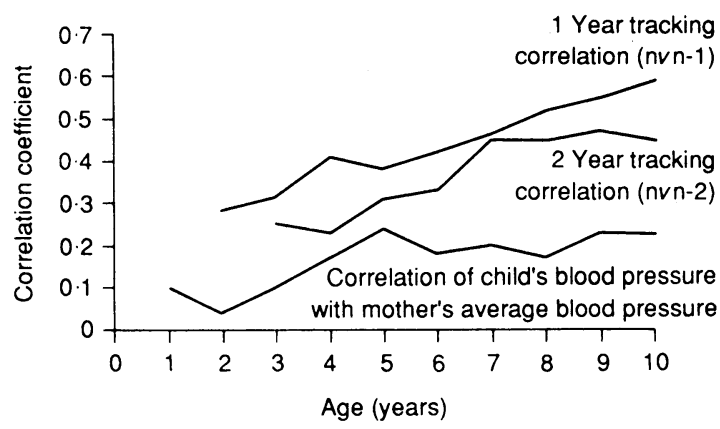

Correlation coefficients for tracking and mothers' average blood pressure with increasing age

\section{Discussion}

The most striking feature of this study was the increase in strength of the tracking coefficient and of the correlation between mother's average and child's blood pressure over the age range 1 year to 10 years, an age range when the overall blood pressure was relatively stable. This suggests that as the children grow older the between occasion variability in blood pressure decreases and they gradually have blood pressures more consistently in one part of the blood pressure distribution. Results of other studies in which children have been followed into adult life ${ }^{9}$ indicate that this part of the blood pressure distribution is likely to be that which they will occupy as adults.

Further work is necessary to identify the factors that influence the children's ultimate blood pressure. Our data confirm the well known familial factor ${ }^{10}{ }^{11}$ which may be particularly marked when measurements are made at school. ${ }^{12}$ We found a relation between children's and mother's blood pressure in particular;
TABLE VI-Correlation coefficients of comparisons of parents' blood pressure and children's blood pressure at different ages (only correlation coefficients $>0.1$ are shown; all are significant at $p<0.05$ )

\begin{tabular}{lcccc}
\hline & \multicolumn{4}{c}{ Blood pressure } \\
\cline { 2 - 5 } $\begin{array}{l}\text { Age of } \\
\text { child }\end{array}$ & Mother & $\begin{array}{c}\text { Mother's } \\
\text { average }\end{array}$ & Father & $\begin{array}{c}\text { Parents' } \\
\text { average }\end{array}$ \\
\hline 6 Months & $0 \cdot 3$ & $0 \cdot 13$ & $0 \cdot 11$ & $0 \cdot 14$ \\
1 Year & & $0 \cdot 10$ & & \\
2 Years & & & & \\
3 Years & $0 \cdot 11$ & $0 \cdot 10$ & & $0 \cdot 11$ \\
4 Years & & $0 \cdot 17$ & & $0 \cdot 18$ \\
5 Years & & $0 \cdot 18$ & & $0 \cdot 24$ \\
6 Years & & $0 \cdot 20$ & $0 \cdot 18$ & $0 \cdot 20$ \\
7 Years & & $0 \cdot 17$ & $0 \cdot 11$ & $0 \cdot 18$ \\
8 Years & & $0 \cdot 23$ & $0 \cdot 12$ & $0 \cdot 25$ \\
9 Years & & $0 \cdot 23$ & & $0 \cdot 21$ \\
10 Years & & & & \\
\hline
\end{tabular}

this is because we took more blood pressure measurements in mothers than fathers and thus had a more representative estimate of maternal blood pressure. Single measurements of maternal blood pressure, even when taken simultaneously with the child's blood pressure (age 4 days to 4 years) gave no stronger correlations than did the father's blood pressure.

We also found that weight became a stronger predictor of blood pressure as the children grew older, with correlation coefficients of about 0.15 in the first years of life increasing to about $0 \cdot 4$ at age 9 to 10 years (table IV). The abnormally high correlation coefficient between weight and blood pressure at age 4 days $(0 \cdot 3)$ may be due to the relation between weight and the maturity of the fetus. Although we believe that all the infants we studied were born after 37 weeks' gestation, this may not have been so and preterm infants have lower blood pressures. ${ }^{13}$

When calculating correlations we adjusted for the effect of cuff size because blood pressures were lower when measured with larger cuffs (tables II and III). Using the largest cuff that can be placed on the child's arm is likely to give the most accurate estimate of blood pressure ${ }^{14}$ as errors from too small a cuff are larger than errors from too big a cuff. Other workers have also found that cuff size influences apparent blood pressure, larger cuffs giving lower blood pressures. ${ }^{2}$ Because heavier children tend to have larger arm circumferences we tended to use the larger cuffs in the heavier children. Although larger cuffs give lower blood pressures, blood pressure was positively though variably correlated with weight and arm circumference (table IV). The effect of using a large cuff therefore tends to oppose the relation of increasing weight to increasing blood pressure.

Because of the variable relation of blood pressure with weight at different ages we could not perform one multiple regression analysis to examine the separate effects of these variables. However, different multiple regression analyses of cuff size, weight, and arm circumference at all ages studied showed that the effect of weight was independent of cuff size; the effect of arm circumference, however, was dependent on

TABLE V-Matrix of correlation coefficients for systolic blood pressure at different ages adjusted for cuff size (only correlation coefficients greater than $0 \cdot 1$ are shown; all are significant at $p<0.0001)$. Figures in parentheses are correlation coefficients adjusted for weight

\begin{tabular}{|c|c|c|c|c|c|c|c|c|c|c|c|c|c|}
\hline Age & 4 Days & 6 Weeks & 6 Months & 1 Year & 2 Years & 3 Years & 4 Years & 5 Years & 6 Years & 7 Years & 8 Years & 9 Years & 10 Years \\
\hline 4 Days & & & $0.18(0 \cdot 17)$ & $0.14(0.13)$ & & & & & & & & & \\
\hline 6 Weeks & & & & & & $0 \cdot 11$ & $0 \cdot 16(0 \cdot 15)$ & $0 \cdot 12(0 \cdot 11)$ & $0 \cdot 16(0 \cdot 15)$ & $0 \cdot 12(0 \cdot 12)$ & $0 \cdot 12(0 \cdot 12)$ & & $0 \cdot 12(0 \cdot 11)$ \\
\hline 6 Months & & & & & & & $(0 \cdot 13)$ & $0 \cdot 16(0 \cdot 15)$ & $0 \cdot 13(0 \cdot 13)$ & $0.14(0.13)$ & & & \\
\hline 1 Year & & & & & $0 \cdot 28(0 \cdot 26)$ & $0 \cdot 25(0 \cdot 24)$ & $0.25(0 \cdot 27)$ & $0.21(0.19)$ & $0 \cdot 17(0 \cdot 16)$ & $0 \cdot 18(0 \cdot 16)$ & $0 \cdot 16(0 \cdot 14)$ & $0.22(0.20)$ & $0.20(0.21)$ \\
\hline 2 Years & & & & & & $0.31(0.29)$ & $0.23(0.21)$ & $0.20(0.29)$ & $0.23(0.25)$ & $0.22(0.26)$ & $0.20(0.24)$ & $0.24(0.27)$ & $0.26(0.23)$ \\
\hline 3 Years & & & & & & & $0.41(0.38)$ & $0.31(0.27)$ & $0.32(0.29)$ & $0.28(0.25)$ & $0.30(0.26)$ & $0.28(0.24)$ & $0.30(0.27)$ \\
\hline 4 Years & & & & & & & & $0.38(0.34)$ & $0.33(0.30)$ & $0.37(0.33)$ & $0.36(0.33)$ & $0.37(0.35)$ & $0.36(0.34)$ \\
\hline 5 Years & & & & & & & & & $0.42(0.42)$ & $0.45(0.45)$ & $0.43(0.43)$ & $0.41(0.41)$ & $0.46(0.43)$ \\
\hline 6 Years & & & & & & & & & & $0.46(0.46)$ & $0.45(0.44)$ & $0.47(0.47)$ & $0.46(0.45)$ \\
\hline 7 Years & & & & & & & & & & & $0.52(0.52)$ & $0.47(0.47)$ & $0.47(0.48)$ \\
\hline 8 Years & & & & & & & & & & & & $0.55(0.55)$ & $0.45(0.45)$ \\
\hline 9 Years & & & & & & & & & & & & & $0.59(0.58)$ \\
\hline
\end{tabular}


cuff size with significant interaction between the two variables. In addition, part of the effect of arm circumference on blood pressure was explained by the correlation of arm circumference and weight.

Although the tracking correlation increased with age to 0.59 at 10 years, the strength of this correlation indicates that tracking accounts for only about $35 \%$ of blood pressure variability in children aged $10 ; 65 \%$ of the variability was between occasion variability. Thus children still have variable blood pressure even at the age of 10 years. We therefore believe that blood pressure is too variable to recommend screening of unselected children at 10 years.

It has recently been shown that geographical factors which affect adult blood pressure independently of social class are already operating in children aged $5-6 .^{2}$ In areas where adults tend to have high blood pressures children have blood pressures 5-6 $\mathrm{mm} \mathrm{Hg}$ higher than children living in low blood pressure areas. ${ }^{2}$ Other studies have shown the importance of dietary sodium, even in the first year of life, in relation to blood pressure.$^{15}$ It is likely that there are other antecedents of high blood pressure apart from those described and cited above, and the evidence of the Brompton study is that childhood would be a profitable time to look for these factors.

We thank the British Heart Foundation and the Medical Research Council for financial support.

\section{Homozygous haemoglobin 0 disease and conjugated hyperbilirubinaemia in a Sudanese family}

\section{S A Ibrahim, Daoud Mustafa, A O Mohamed, M Beshir Mohed}

\section{Departments of}

Biochemistry and

Medicine, Faculty of

Medicine, PO Box 102,

Khartoum, Sudan

S A Ibrahim, MRCP, professor of biochemistry

Daoud Mustafa, FRCP, professor of medicine A O Mohamed, MB, teaching assistant, biochemistry M Beshir Mohed, DIP MALARIA, chief laboratory assistant, biochemistry

Correspondence to: Professor Ibrahim.

$B M \mathcal{F} 1992 ; 304: 26-7$
Haemoglobin O Arab was first reported in two children of an Arab family who were suffering from sickle cell Hb O trait.' In the Sudan 11 instances of the carrier trait for $\mathrm{Hb} \mathrm{O}$ were found in 9100 unselected blood samples in Khartoum. ${ }^{2}$ Homozygosity for Hb O Arab has hitherto not been reported. We describe three cases of homozygous $\mathrm{Hb} \mathrm{O}$ Arab with conjugated hyperbilirubinaemia in a Sudanese family.

\section{Case reports}

CASE 1

A Sudanese woman aged 27 was admitted to Khartoum Teaching Hospital in 1989 complaining of fever, jaundice, and a painful vulval swelling. Since the age of 8 years she had suffered from repeated attacks of jaundice, often precipitated by bouts of fever. In 1981 and 1987 she had been admitted to hospital and was diagnosed as having haemolytic anaemia. On admission in 1989 , she had a temperature of $38.9^{\circ} \mathrm{C}$ and a spleen that was just palpable. She had a small abscess in

Laboratory findings in three patients with homozygous $\mathrm{Hb} O$ disease (cases 1-3) and their brother (case 4)

\begin{tabular}{|c|c|c|c|c|c|c|c|c|c|}
\hline \multirow[b]{2}{*}{$\begin{array}{l}\text { Case } \\
\text { No }\end{array}$} & \multirow[b]{2}{*}{$\begin{array}{c}\text { Age } \\
\text { (years) }\end{array}$} & \multirow[b]{2}{*}{$\begin{array}{l}\text { Height } \\
(\mathrm{cm})\end{array}$} & \multirow[b]{2}{*}{$\begin{array}{l}\text { Weight } \\
(\mathrm{kg})\end{array}$} & \multirow[b]{2}{*}{$\begin{array}{c}\text { Adult } \\
\text { haemoglobins }\end{array}$} & \multirow[b]{2}{*}{$\begin{array}{l}\text { Haemoglobin } \\
\mathrm{g} / \mathrm{l}\end{array}$} & \multirow{2}{*}{$\begin{array}{l}\text { Haemoglobin } \\
\qquad \mathrm{F}(\%)\end{array}$} & \multirow{2}{*}{$\begin{array}{c}\text { Reticulocytes - } \\
(\%)\end{array}$} & \multicolumn{2}{|c|}{$\begin{array}{l}\text { Serum bilirubin } \\
(\mu \mathrm{mol} / \mathrm{l})\end{array}$} \\
\hline & & & & & & & & Total & Conjugated \\
\hline 1 & 27 & 140 & 46 & $\mathrm{O}$ & 117 & $1 \cdot 2$ & $5 \cdot 8$ & $129 \cdot 2$ & $47 \cdot 6$ \\
\hline 2 & 23 & 144 & 48 & $\mathrm{O}$ & 112 & $2 \cdot 3$ & $3 \cdot 3$ & $59 \cdot 5$ & $32 \cdot 3$ \\
\hline 3 & 15 & 132 & 36 & $\mathrm{O}$ & 101 & $1 \cdot 3$ & $3 \cdot 8$ & $51 \cdot 0$ & $28 \cdot 9$ \\
\hline 4 & 12 & 138 & 43 & $A$ and $O$ & 95 & 0.5 & 3 & $42 \cdot 5$ & $30 \cdot 6$ \\
\hline
\end{tabular}

1 Burke GL, Voors AW, Shear CL, Webber LS, Smoak CG, Cresanata JL, et al. study of children aged 5-7 years. BMF 1989;299:587-91.

3 Task Force on Blood Pressure Control in Children. Report on the second task force on blood pressure control in children, 1987. Pediatrics 1987;79:1-25.

4 de Swiet M, Fayers P, Shinebourne EA. The value of repeated blood pressure measurements in children -the Brompton study. BMF 1980;280: 1567-9.

5 de Swiet M, Fayers $P$, Shinebourne EA. Blood pressure in 4 and 5 year old children: the effects of environment and other factors in its measurement. The Brompton study. F Hypertens 1984;2:501-5.

6 de Swiet M, Fayers P, Shinebourne EA. Systolic blood pressure in a population of infants in the first year of life: the Brompton study. Pediatrics 1980; 65:1028-35.

7 de Swiet M, Fancourt R, Peto J. Systolic blood pressure variation during the first 6 days of life. Clin Sci 1975;49:557-61.

8 Cole TJ. Weight/height ${ }^{\circ}$ compared to weight/height ${ }^{2}$ for assessing adiposity in $1986 ; 13: 433-51$

9 Rosner B, Hennekens CH, Kass EH, Miall WE. Age-specific correlation analysis of longitudinal blood pressure data. Am $\mathcal{F}$ Epidemiol 1977;106: 306-13.

10 Clarke WR, Schrott HG, Burns TL, Sing CF, Laver RM. Aggregation of blood pressure in the families of children with labile high systolic blood pressure. The Muscatine study. Am f Epidemiol 1986;123:67-80.

11 Shear CL, Burke GL, Freedman DS, Berenson GS. Value of childhood blood pressure status: results from 8 years of follow-up in the Bogalusa heart study. Pediatrics 1986;77:862-9.

12 Wilson PD, Ferencz C, Dischinger PC, Brenner JI, Zeger SL. Twenty four hour ambulatory blood pressure in normotensive adolescent children of hypertensive and normotensive patients. Am $f$ Epidemiol 1988;127:946-54.

13 Versmold HT, Kitterman JA, Phibbs RH, Gregory GA, Tooley WH. Aortic beod pressure during the first 12 hours of life in infants with birth weight
blood

14 de Swiet M, Dillon MJ, Littler WAW, O'Brien E, Padfield PL, Petrie JC. Measurement of blood pressure in children. BMF 1989;299:497

15 Hofman A, Hazebroek A, Valken Burg HA. A randomised trial of sodium intake and blood pressure in new born infants. JAMA 1983;250:370-3.

(Accepted 18 October 1991) Blood pressure. Pediatrics 1987;80(suppl):784-8.

2 Whincup PH, Cook DH, Shaper AG. Early influences on blood pressure: a childhood: influence of age and bone age during puberty. Ann Hum Biol pressure measurements and family history in predicting future blood

the vulva, which was drained. Investigations showed a haemoglobin concentration of $117 \mathrm{~g} / 1$, a white cell count of $8.6 \times 10^{9} / 1$, an erythrocyte sedimentation rate of $24 \mathrm{~mm}$ in the first hour (Westergen), and a negative blood film for malaria. Paper electrophoresis of haemoglobin in barbitone buffer $(0.05 \mathrm{M}, \mathrm{pH} \mathrm{8.6)}$ detected $\mathrm{Hb} \mathrm{O}$ Arab alone, which was subsequently confirmed by Professor Sir David Weatherall of the Nuffield Department of Clinical Medicine, Oxford. The table shows the rest of the findings.

Her urine contained excess urobilinogen but no bilirubin. The coproporphyrin content of urine was normal but thin layer chromatography showed a preponderance of isomer $\mathrm{I}^{3}$ After treatment she was discharged taking $5 \mathrm{mg}$ folate daily.

CASES 2 AND 3

The table shows the findings in two younger sisters of the patient in case 1 (cases 2 and 3). In both cases urine examination showed excess urobilinogen but no bilirubin. Coproporphyrin concentrations were within normal limits with a preponderance of isomer I.

Case 4 is of a younger brother of the patients in cases 1-3 who was found to have conjugated hyperbilirubinaemia with a preponderance of urinary coproporphyrin I.

\section{Comment}

The clinical picture of homozygous $\mathrm{Hb} \mathrm{O}$ Arab has hitherto not been reported. The members of this family are northern Sudanese of Arab ancestry. Homozygous $\mathrm{O}$ disease seems to start early in childhood and is always preceded by a febrile illness. Although malarial infection was suspected at various times in these three cases, the parasite was never detected in a peripheral blood film. It seems possible that in homozygous $\mathrm{Hb} \mathrm{O}$ erythrocytes infected with the malaria parasite undergo immediate haemolysis and are eliminated from the circulation. This is supported by the fact that haemoglobin concentration was low $(75 \mathrm{~g} / \mathrm{l})$ in the patient in case 1 when she was admitted to hospital in 1987. Thus Hb O Arab seems 